\title{
Double Inlet Left Ventricle (DILV), Double Outlet Left Ventricle (DOLV), Malposition of Great Arteries, Inlet Ventricle Septal Defect (VSD) and Patent Ductus Arteriosus
}

\author{
Sylvie Sakasasmita, Ganesja M. Harimurti, Dicky Fakhri, Venty
}

' General Practitioner Siloam Hospitals Kebon Jeruk Department of Cardiology and Vascular Medicine Siloam Hospitals Kebon Jeruk

${ }^{3}$ Department of Thoracic and Cardiovascular Surgery Siloam Hospitals Kebon Jeruk
Congenital heart disease is an interesting area which present a great various arrangement of the cardiac stucture. We present a rare case of I I months old male with complex congenital heart disease consisted of Double Inlet Left Ventricle (DILV), Double Outlet Left Ventricle (DOLV) with Malposition of Great Arteries, Inlet Ventricle Septal Defect (VSD) and Patent Ductus Arteriosus (PDA).

Patient was an eleven months old male who was admitted in our institution for cardiac operation. He was diagnosed with congenital heart disease since three days old with initial presentation of cyanosis when he was crying. His physical growth was retarded but his developmental Milestones was considered normal. On admission, his oxygen saturation was $88 \%$ with ambient air. The diagnosis was confirmed by echocardiography. He was planned to undergo staging surgery which would end to Fontan Procedure. Pulmonary Artery (PA) banding was performed to reduce blood flow to pulmonary circulation, distribute more blood from the left ventricle to aorta and systemic circulation and prepare for bidirectional Glenn Shunt procedure one year later and Fontan procedure a year after that.

(J Kardiol Indones. 20I5;36:I57-6I)

Keywords: DILV, DOLV, PA banding, Fontan procedure 
Jurnal

Kardiologi Indonesia

J Kardiol Indones. 2015;36:157-6I

ISSN $0126 / 3773$

\title{
Double Inlet Left Ventricle (DILV), Double Outlet Left Ventricle (DOLV), Malposisi Pembuluh Darah Besar, Ventricle Septal Defect (VSD) Inlet, dan Patent Ductus Arteriosus
}

\author{
Sylvie Sakasasmita, Ganesja M. Harimurti, Dicky Fakhri, Venty
}

\begin{abstract}
Penyakit jantung kongenital merupakan area kardiologi yang menarik karena presentasi dari stuktur jantung yang terjadi dapat sangat bervariasi. Disini kami memaparkan sebuah kasus pada anak laki-laki berusia 11 bulan dengan penyakit jantung kongenital kompleks yang terdiri dari inlet ventrikel kiri ganda, outlet ventrikel kiri ganda dengan malposisi arteri besar, defek septum ventrikel inlet dan duktus arteriosus paten.

Pasien laki-laki sebelas bulan dirawat di institusi kami dengan perencanaan tindakan operasi. Sebelumnya, pasien terdiagnosa memiliki penyakit jantung congenital sejak usia tiga hari dengan presentasi awal berupa sianosis ketika menangis. Pertumbuhan fisiknya pun terhambat namun perkembangannya menurut Milestones masih tergolong normal. Saat masuk ruang perawatan saturasi oksigen $88 \%$ tanpa suplementasi oksigen. Diagnosis dikonfirmasi dengan menggunakan echokardiografi dan pasien direncanakan untuk mendapatkan tindakan pembedahan yang berakhir pada prosedur Fontan. Pengikatan arteri pulmonaris dilakukan telebih dahulu pada perawatan ini dengan tujuan untuk mengurangi aliran darah ke sirkulasi pulmonal, mendistribusikan lebih banyak darah dari ventrikel kiri ke aorta dan sirkulasi sistemik dan mempersiapakan untuk prosedur bidirectional Glenn Shunt satu tahun kemudian dan prosedur Fontan satu tahun setelahnya.
\end{abstract}

(J Kardiol Indones. 2015;36:157-61)

Kata kunci: DILV, DOLV, pengikatan arteri pulmonalis, prosedur Fontan

\section{Background}

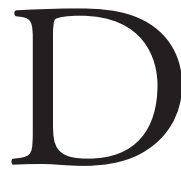

ouble Inlet Left Ventricle (DILV) is a rare cardiac malformation which contribute only $1 \%$ of congenital heart disease. ${ }^{1}$ DILV is one of cyanotic functional univentricular congenital heart disease. Herein, we report a rare case with Double Inlet Left Ventricle (DILV) and Double Outlet Left Ventricle (DOLV) with Malposition of Great Arteries, Inlet Ventricle
Alamat Korespondensi:

dr. Sylvie Sakasasmita, Siloam Hospitals Kebon Jeruk

Jl. Gedung Panjang No. 7B RT 4/RW 10 jakbar I I 240

Tel.085776I I6I37. E-mail: sylviesakasasmita@gmail.com 
Septal Defect (VSD) and Patent Ductus Arteriosus (PDA).

\section{Case}

Patient was an eleven months old male who was admitted for the first time to our institution for heart surgery. Patient was born term to a 26 years old G2P1A0 mother with uneventful pregnancy with birth weight of 2480 grams. On 3 days old, he was noted to have cyanosis when he was crying and murmur on chest auscultation, hence he was diagnosed to have congenital heart disease by Pediatrician.

Two-Dimensional echocardiography (2D Echo) was not done at that time. He was not given maintenance medication. On 11 months old, his physical growth was retarded $(6.5 \mathrm{kgs})$ but his developmental Milestones was considered normal. The cyanosis was increased, hence he was brought to Pediatric Cardiologist. Two-Dimensional echocardiography revealed hypoplasia of right ventricle, with hyperthropy of left ventricle. Both of the ventricle chamber was connected through inlet ventricle septal defect (VSD). Mitral and tricuspid valve were connected to left ventricle (Figure 1). Aorta and pulmonary artery were arising from left ventricle (Figure 2). Stretched Patent foramen ovale (PFO) (L-R) shunt. He also has a big Patent Ductus Arteriosus (PDA). There's no pulmonary stenosis. Then, he was scheduled for the surgery.

Upon admission, he was fretful, with central and peripheral cyanosis. Cardiac rate of 110 beats per minute and oxygen saturation of $88 \%$ with ambient air. On chest examination, breath sound was clear and holosystolic murmur grade 3/6 was best heard

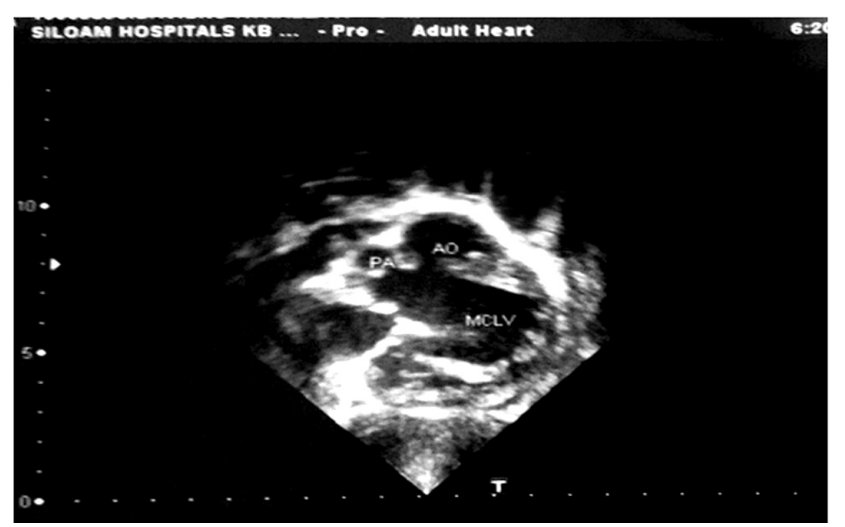

Figure 2. Double Outlet Left Ventricle

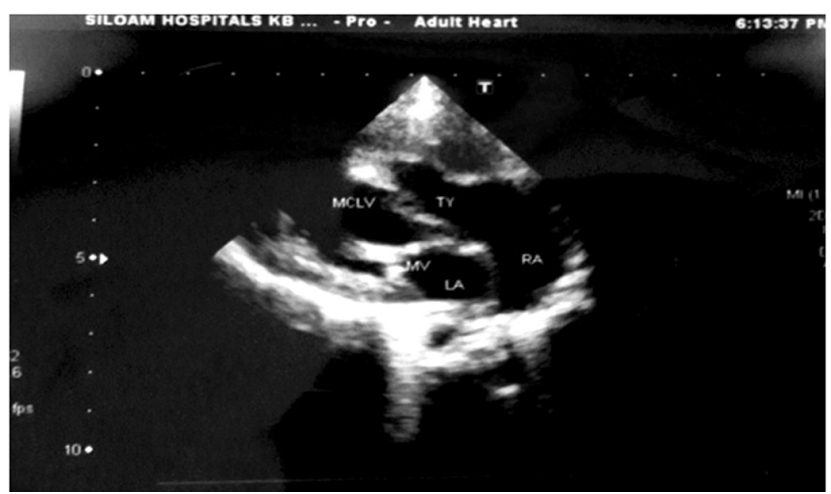

Figure 1. Double Inlet Left Ventricle

at left lower sternal border. His chest x-ray showed cardiomegaly.

He was planned to undergo staging surgery which would end to Fontan Procedure. During this admission, we would perform surgery to narrow the inlet of pulmonary artery procedure called Pumonary Artery (PA) banding. During surgery, we found that the PA diameter is two times bigger than the aorta, PDA size was $3 \mathrm{~mm}$. The PA banding was done without any complication. Post PA banding, his blood pressure was $88 / 40(52) \mathrm{mmHg}$ with heart rate of 140 beats per minute and $\mathrm{SpO} 2$ of $80-85 \%$. Distal PA banding pressure was 29-30/16-18 $\mathrm{mmHg}$. PDA was also ligated on this surgery. Then, patient transferred to Pediatric ICU (PICU) for post operation care. On third post operation day, the patient was stable hence transferred to the general ward. He was discharged on sixth post operation day. On three months after surgery follow up, PA banding showed good evaluation with pressure gradient of $68 \mathrm{mmHg}$ (Figure 3). He was scheduled to undergone bidirectional Glenn shunt procedure one year later and Fontan procedure a year after bidirectional Glenn shunt procedure.

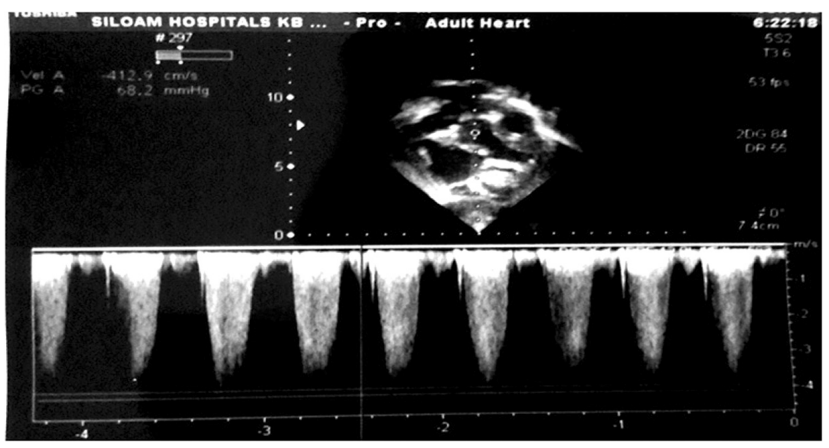

Figure 3. Post PA Banding Pressure Gradient 
Jurnal Kardiologi Indonesia

\section{Discussion}

Double inlet ventricle is a condition where the atrioventricular valve (mitral valve and tricuspid valve) are connected to a main single chamber. Eighty percent of double inlet ventricle is double inlet left ventricle (DILV) where both left and right atrium are connected to left ventricle (mitral valve and tricuspid valve open to the left ventricle as the main single ventricle). ${ }^{2}$ The right ventricle is underdevelop/hypoplasia. Usually this condition is combined with ventricular septal defect so the oxygenated and deoxygenated blood mix in the single ventricle. ${ }^{3}$

Many affected patients have associated defects in the heart or main arteries, including pulmonary stenosis, pulmonary atresia, other valve abnormalities or coarctation of the aorta. ${ }^{4}$ The pulmonary artery is stenosis in $50 \%$ patient makes the patient cyanosis due to decrease in pulmonary blood flow. When the pulmonary valve is normal, pulmonary blood flow is excessive and saturations are near normal. Our patient had no pulmonary stenosis, but in our patient the cyanosis primarily due to mix of the blood from right ventricle and left atrium.

Eighty five percent cases DILV are combined with transposition of great arteries where aorta arise from right ventricle and pulmonary arteries from left ventricle. ${ }^{2}$ But in this case we found malposition of great arteries, described by both of aorta and pulmonary arteries arise from left ventricle. Then, the great arteries and left ventricle are connected via aorta and pulmonary valve or known as double outlet left ventricle (DOLV). Double outlet ventricle is an uncommon cardiac anomaly that contributes $1 \%$ of congenital heart disease. Meanwhile, double outlet left ventricle (DOLV) accounts for less than $5 \%$ in double-outlet ventricle cases. ${ }^{5}$ Patent ductus arteriosus in DOLV itself didn't give any significant clinical changes.

All of the arrangement of this cardiac structure cause several problems, such as: 1) big burden for left ventricle to receive additional blood from systemic circulation to be pumped out to pulmonary arteries 2) overflow of pulmonary artery 3) mixing of oxygenated and deoxygenated blood. In order to overcome this situation, we need to separate pulmonary and systemic circulation completely by surgical procedure, called Fontan procedure which is the last staged operation for congenital heart disease who cannot be offered biventricular repair. ${ }^{6-8}$

The objective of Fontan procedure is to completely bypass the right heart. It was first reported by Fontan and Baudet in 1971 as palliative surgical procedure for tricuspid atresia. ${ }^{8}$ The systemic circulation will have direct connection to pulmonary arteries without passing through the right heart chambers. The dominant (single) ventricle would receive blood from pulmonary veins and pump the blood to the systemic circulation. There are several criterias for the Fontan operation includes ; 1 . Minimum age of 4 years, 2 . Sinus rhythm, 3. Normal caval drainage, 4. Right atrium of normal volume, 5. Mean pulmonary artery pressure $\leq 15 \mathrm{mmHg}, 6$. Pulmonary arterial resistance $<4 \mathrm{U} / \mathrm{m}^{2}, 7$. Pulmonary artery to aorta diameter ratio equal to $0.75,8$. Normal ventricular function (ejection fraction $>0.6$ ), 9. Competent left atrioventricular valve, 10. No impairing effects of previous shunts. ${ }^{1,8}$

In some cases indicated for Fontan circulation, pulmonary artery banding is needed to prevent pulmonary vascular disease. The primary objective of performing pulmonary artery banding is to reduce excessive pulmonary blood flow and protect the pulmonary vasculature from hypertrophy and irreversible pulmonary hypertension. The blood flow was also more directed to aorta to the systemic circulation. ${ }^{9}$ Patent ductus arteriosus ligation has also been done in this case to reduce aorta to pulmonal artery shunting and improve blood flow to systemic circulation

Our patient is scheduled for catheterization to measure the pulmonary arteries pressure after 6 month-1 year after surgery. If PA pressure is low, the next step of surgery will be bidirectional Glenn Shunt procedure as a preliminary step to facilitate Fontan circulation. This procedure must be done to make the anastomosis between the superior vena cava and the right pulmonary artery, consequently volume load to single ventricle is reduced. In bidirectional Glenn the superior vena cava (SVC) is divided at its junction with the right atrium, the atrial end is sewed, end-to-side anastomosis is created between the SVC and the right pulmonary artery. ${ }^{7,8,10}$ After that, Fontan procedure would be done to complete single ventricular repair. In this case the Fontan completion is planned to be accomplished by sewing an extracardiac conduit in an end-to-end fashion to the IVC and in an end-to-side to the pulmonary artery confluence or distal SVC. ${ }^{10}$

\section{Summary}

Pulmonary artery banding had been done to an eleven months old male patient with complex congenital 
heart disease with DILV, DOLV, malposition of great arteries, inlet VSD and PDA to reduce pulmonary artery pressure and prevent pulmonary hypertension as preparation for bi-directonal Glenn Shunt procedure. Fontan or univentricular repair is the final procedure which is frequently employed in this cardiac malformation.

\section{References}

1. Khairy P, Poirer N, Mercie LA. Univentricular Heart .Circulation. 2007; 115:800-812.

2. Children's Hospital and Clinic Minnesota. 2012. Available from: http://www.childrensheartclinic.org/DiagnosisIllustrations/ DILV.pdf

3. Kaneshiro NK. Double Inlet Left Ventricle.2012. Available from: http://www.nlm.nih.gov/medlineplus/ency/article/007327.htm
4. The Royal Children's Hospital Medicine. Double Inlet Left Ventricle (DILV). Available from : http://www.rch.org.au/cardiology/heart_defects/Double_Inlet_Left_Ventricle_DILV/

5. Hok KC, Jieh NW, Wen PH, Wen LY, Jing MW. DoubleOutlet Left Ventricle with Ebstein Anomaly in a Neonate with VACTERL Association. Acta Cardiol Sin 2011;27:65_7

6. Vyas H, Hagler DJ. Double Inlet Left Ventricle. Current Treatment Options in Cardiovascular Medicine 2007;9: 391-398.

7. Kanakis MA, Petropoulos AC, Mitropolus F. Fontan Operation. Hellenic J Cardiol 2009; 50: 133-141

8. Gewillig M. The Fontan Circulation. Heart 2005;91:839846.

9. Bhimji S. Pulmonary artery banding. Available from: http:// emedicine.medscape.com/article/905353-overview

10. Pelletier G, Jacobs M. Superior Cavopulmonary Anastomosis: The Hemi-Fontan and Bidirectional Glenn. 2013. Available from: http://www.ctsnet.org/sections/clinicalresources/congenital/expert_tech-6 